\title{
Red faces (and hot tempers) on 2,4,5-T
}

The controversy over the use of the herbicide 2,4,5-T in the United Kingdom became even more heated last week with the revelation of a difference of opinion between government agencies over how to determine the safety of the herbicide. Thus Mr John Locke, the director-general of the Health and Safety Executive (HSE), pleaded for a more effective relationship between the executive and the Advisory Committee on Pesticides (PAC) of the Ministry of Agriculture, Fisheries and Food (MAFF).

Locke was speaking at the opening of a new HSE centre at the Royal Show (see page 100). His call for more "tying up" between HSE and PAC is, on the surface, a plea for more rationality in the review processes for toxic substances, but it underscores the strain both organizations are suffering in determining the safety or otherwise of 2,4,5-T.

The director-general's comments were voiced two days before a meeting of the HSE's Advisory Committee on Toxic Substances (ACTS), where 2,4,5-T was the main item on the agenda. Like all HSE advisory committees, ACTS has representatives from both the Trades Union Congress (TUC) and the Confederation of British Industries (CBI). With the TUC already on record as calling for a ban on $2,4,5-T$, feelings were bound to run high. By all accounts it was a stormy meeting, with the TUC representatives expressing their dissatisfaction with PAC's review processes for herbicides and pesticides.

As a general rule, the TUC's representatives on ACTS believe that, where issues of health and safety are concerned, HSE should be responsible. The unions suspect the impartiality of MAFF in reviewing the toxicity of chemicals which can be of benefit to agriculture. At the meeting last week, they asked why PAC claimed in its eighth review of 2,4,5-T (published in March last year) that only three tonnes of the herbicide were used annually in Britain, when the real figure is now known to be about twenty times as much. They also want to know the names of all UK manufacturers importing, exporting or selling products containing 2,4,5-T.

Recent Customs and Excise figures confirm that some 116 tonnes of 2,4,5-T were imported into the UK in 1979 . With the publication of these revised estimates, the unions are all the more sceptical of the review processes.

MAFF is seriously embarrassed by the error about the tonnage of 2,4,5-T used in Britain. PAC had assumed - wrongly that the Forestry Commission was the largest user of the herbicide in the UK, and the three tonne figure was based on 2,4,5-T use in silviculture. It is now known that far more 2,4,5-T is used on grassland; on the

basis of a recent survey, the use of 2,4,5-T in Britain last year is now put at 58 tonnes.

One especially serious aspect of the affair is that the PAC estimates were given to the Royal Commission on Environmental Pollution during its inquiry into agricultural pollution. In the report of this inquiry published last year, the royal commission gave 2,4,5-T a clean bill of health, partly on the grounds that British usage was relatively small. Members of the commission were wondering this week how the record should be set straight.

PAC is now reviewing the herbicide for the ninth time in the light of information about $2,4,5-\mathrm{T}$ and its dioxin $(2,3,7,8$-tetrachlorodibenzo- $p$-dioxin) contaminant published in the past two years.

The subcommittee responsible, on the instructions of Mr Peter Walker, Minister of Agriculture, has now met a delegation from the National Union of Agricultural and Allied Workers (NUAAW) to hear the union's case against 2,4,5-T. In three and a half hours of often heated discussion, the union delegation insisted that 2,4,5-T should be banned. The delegation was told that the dioxin content of 2,4,5-T now set at a maximum of 0.01 parts per million in the UK is so low that it represents no threat. The herbicide itself is a teratogen in some rodent species at concentrations of 35 milligrams per kilogram of body weight, 10,000 times the concentrations at which

\section{Supreme Court reprieves benzene}

\section{Washington}

Strict regulation of toxic substances must be backed up by adequate scientific data on their potential danger. This was the message delivered by the US Supreme Court last week when it rejected a proposal by the Department of Labor's Occupational Safety and Health Administration (OSHA) to reduce permitted exposure levels to benzene to one part per million.

Following evidence which emerged in the early 1970 s of a link between benzene exposure and various blood disorders - in particular, leukaemia - OSHA produced new regulations in 1977 which would have reduced permitted exposure levels from the current 10 parts per million.

The proposed regulation has been attacked by the chemical and petroleum industries, where more than a million workers are exposed to benzene in products from gasoline additives to paint solvents. The industries claimed that the regulations were unnecessarily restrictive; and that the cost of meeting them - measured in hundreds of millions of dollars - was incommensurate with the expected benefits.

Using such arguments, the American Petroleum Institute last year persuaded a dioxin is a teratogen. With the new $2,4,5-\mathrm{T}$ formulation, 2,4,5-T will exert a teratogenic effect before dioxin.

The subcommittee also believes that there is a sufficient safety factor in the assessment of the carcinogenic risks from dioxin. The most reliable study suggests that dioxin is a carcinogen at dose levels of 0.1 microgram per kilogram of body weight per day in rodents. With the new formulation, to consume such a quantity of dioxin, rodents would need to take in $2,4,5$ - $\mathrm{T}$ at concentrations about one-tenth to a half of their body weight.

The subcommittee's recommendations on 2,4,5-T will be considered at a PAC meeting on 24 July. The same evidence will also be reviewed at a special meeting of ACTS at the end of August. Whatever the outcome of these meetings, it is clear that the trade union campaign against $2,4,5-\mathrm{T}$ has had a considerable effect on HSE and MAFF.

The unions see the visit of the NUAAW deputation to the PAC scientific subcommittee as a precedent. But it is unlikely that the trades unions will be satisfied with this modest advance. The unions are openly campaigning for a change in the review process, and it was only natural that John Locke should appeal to MAFF for some help in devising a system which will satisfy all parties.

Alastair Hay

judge in New Orleans to rule the proposed regulation invalid. Much attention had been focused on OSHA's decision to appeal to the Supreme Court, largely because the judge critized OSHA for not weighing the expected benefits of the regulations against the costs of meeting them.

In the event, the Supreme Court skirted around the cost-benefit issue. Only one member - Justice Lewis Powell - insisted that a full cost-benefit analysis should have been carried out; and the matter awaits resolution in two further cases which the court has agreed to hear next year.

No less significant, however, is the substance of the court's ruling in a case which Chief Justice Warren Burger described as raising "difficult unanswered questions on the frontiers of science and medicine". The court ruled that OSHA must demonstrate that a toxic chemical poses a "significant" risk before making a regulation.

This judgement directly undermines one of the fundamental principles on which OSHA's regulatory strategy is at present based. So far, the agency has argued that, where a chemical is suspected of having low-level toxic effects but the scientific and epidemiological evidence is insufficient to characterize these precisely, it must be 
assumed that there is no threshold below which the chemical can be considered "safe" - and industry is required to lower exposure to the limits of technological feasibility.

OSHA acted on benzene even though the evidence of increased leukaemia incidence among workers in Turkey and Ohio involved people who had been exposed to considerably more than $10 \mathrm{ppm}$ over long periods of time.

The agency argued that only a technological feasibility strategy would suffice to guarantee the protection of workers, but the Supreme Court, in a 5-4 vote, agreed with industry critics that a more thorough scientific and technological justification must be produced. Admitting the existence of considerable uncertainties, the court accepted that the agency is not required to prove its point "with anything approaching scientific certainty".

Even so, in writing the majority opinion, Justice John Stevens said that OSHA had failed to produce "substantial evidence" that the new benzene rules were "reasonably necessary and appropriate" to remedy a "significant risk of material health impairment'". OSHA, he said, had not produced empirical evidence or scientific opinion to show that exposure to benzene at or below the $10 \mathrm{ppm}$ level had in fact caused cancer.

Predictably, the court's decision has been welcomed by industry, which has long protested at the expense of meeting the "lowest technologically feasible" criterion. Agency officials admitted that they were "disappointed" with the ruling, but vowed to press on with regulating benzene and other toxic substances.

The closeness of the Supreme Court's decision and the fact that different members gave different reasons for concurring are likely to cushion the impact. Indeed, if OSHA can produce more evidence on benzene, then the tough standard could still stand.

In a strongly worded dissenting opinion, four of the nine justices said they felt OSHA had already produced enough evidence to justify the low exposure limit. And a fifth said that, given additional evidence, he might be persuaded by OSHA's case.

David Dickson.

\section{Soviet environment}

\section{Spending more}

Soviet capital investment in environmental protection and the conservation of endangered species will be trebled in the next Five Year Plan (1981-1985), according to what TASS has described as "preliminary data". Since the official figures for the present plan include 11,000 million rubles of direct state funding and 50,000 million from the budgets of industrial enterprises and institutions, this suggests an investment of at least 180,000 million rubles $(£ 125,000$ million) in the next five years.

The TASS announcement followed the passing of two major environmental bills, on clean air and the protection of fauna, by the Supreme Soviet. Enactment of the laws was preceded by unusually extensive reporting in Pravda, perhaps because of the undoubted pride which the members of the Supreme Soviet show in their progress to date. No other country, observed Deputy P.P. Vavilov, president of the AllUnion Academy of Agricultural Sciences, has on its statute books laws of comparable scope, which even protect insects and soil fauna with a direct bearing on soil fertility.

Vavilov nevertheless emphasized that, even when the act becomes law in 1981, further research will be needed to ensure that its provisions are implemented in strict accordance with ecological principles.

What nobody mentioned in the debate, but what must surely have been in the minds of many of the deputies - especially those from central Russia, central Asia, Byelorussia and Estonia - was the present threat from wolves and wolf-dog crossbreeds which, according to some estimates, have doubled in numbers over the past ten years, following cutbacks in hunting and the disbanding of skilled hunting teams. The threat is particularly acute in Estonia.

No less complex are the management problems raised by the clean air bill. Air pollution has been a major problem in many Soviet cities for a considerable time, and one of the earliest preparations for the Moscow Olympic Games was the designing village, to reduce the effect of petrol fumes of electric runabout cars for the Olympic

on the athletes.

Not only cities are at risk, however. In the Supreme Soviet debate, Deputy V.M. Kanun from Zhitomir spoke of the pollution threat to the Polessian forests in spite of the expenditure, during the current Five Year Plan, of "tens of millions of rubles" on anti-pollution measures. Deputy Yu. A, Izrael', Chairman of the State Committee on Hydrometeorology and Environmental Monitoring, observed that the Union-wide anti-pollution monitoring service now has air-pollution monitoring projects in 450 cities; nevertheless, as Deputy Kipel' observed, “many plants and factories go on polluting the atmosphere and water in the same old way".

Water, in fact, is not specifically the subject of the new legislation, although, according to Deputy Izrael', progress in this field is one of the "major successes" of the environmental control programme. "Almost all the rivers of the European part of the USSR", he said, "have become cleaner".

Nevertheless, water may well soon be better regulated. A 200-person multidisciplinary research team, led by Vladimir Lazanskii, head of the All-Union Research Institute for Water Conservation, has completed a detailed computer analysis of the ecology of 26 of the largest rivers in the USSR and fifteen seas and lakes. On the basis of this study, the team has put forward several proposals ranging from the automated control of water conservation complexes and the introduction of closedcycle processes for metallurgical works to the special processing of rain water and snow melt bearing particles of petroleum products.

Vera Rich

\section{Industrially financed research, OECD countries}

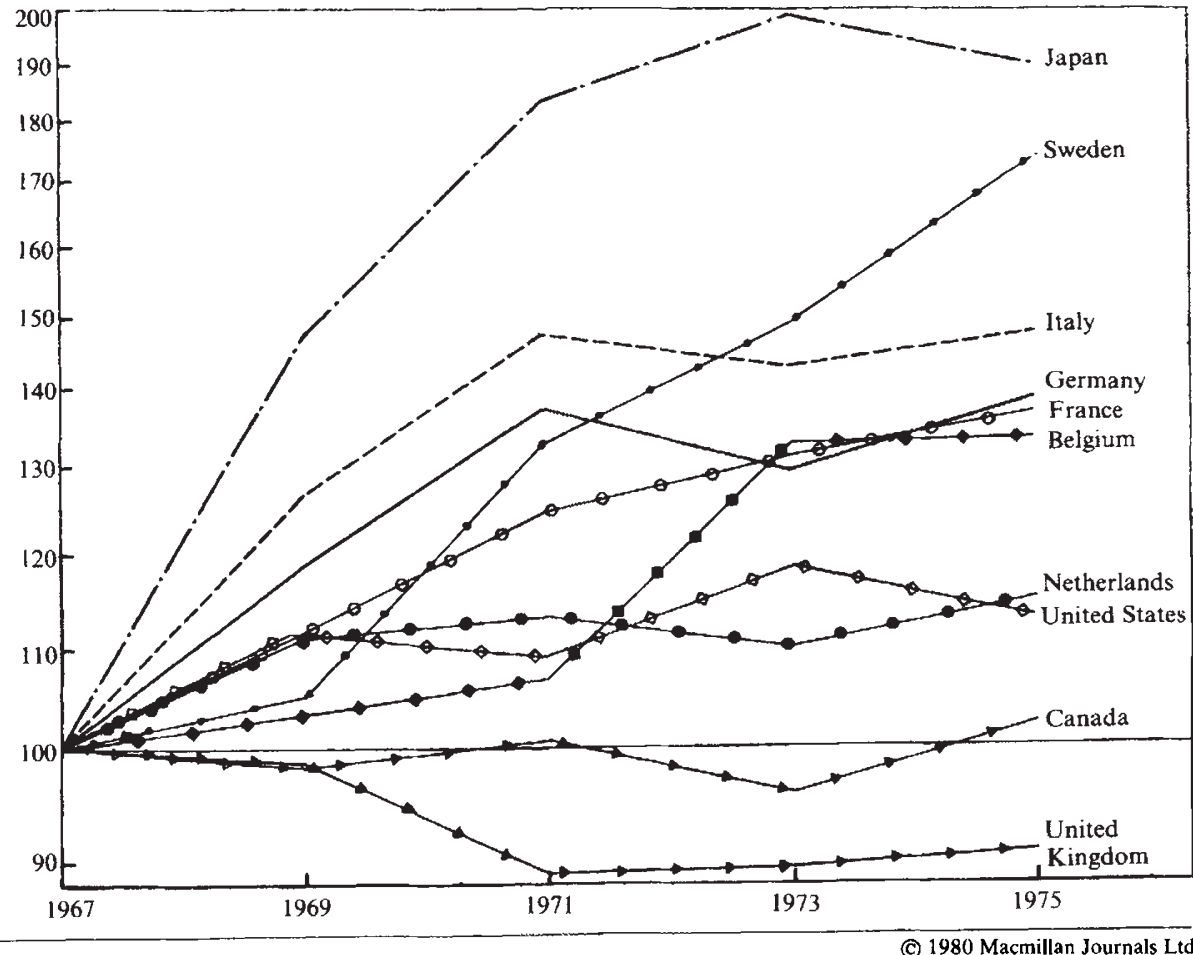

